\title{
As Nações-Unidas e a definição de agressão *
}

\author{
Ataliba Nogueira \\ Delegado do Brasil à XII Assembléia \\ Geral das Nações-Unidas
}

\begin{abstract}
A definição de agressão ocupa as Nações Unidas desde 1950.
\end{abstract}

Mesmo antes, na conferência de São Francisco, a comissão de que era relator Paul Boncour já havia considerado a questão e decidira, sàbiamente, não incluir na Carta das Nações Unidas a definição de agressão.

Grande número de estados se interessou, desde 1950, em formular tal definição e fazê-la aprovar mediante resolução da Assembléia Geral. Em conseqüência, a definição de agressão foi estudada e discutida abundantemente. Não tenho necessidade de relembrar, neste momento, o histórico dos esforços da Assembléia geral à procura da definição de agressão. Tais esforços, da parte dos governos, de juristas e diplomatas eminentes, são sem dúvida extremamente interessantes e constituem valiosa contribuição ao estudo da matéria, cuja importância não se poderá negar. E não serão perdidos.

Mas, se há conclusões que os referidos esforços provaram e confirmaram, são elas, em primeiro lugar, a extrema dificuldade técnica de uma formulação da matéria; segundo, a impossibilidade de chegar-se a definição satisfatória para grande número de estados, inclusive os mais poderosos; e, por fim, a inoportunidade da definição de agressão.

(*) 0 presente trabalho foi apresentado à $12 .^{\text {a }}$ Assembléia geral das Nações Unidas, tendo sido amplamente comentado na obra de Eugène Aroneanu, "La définition de l'agréssion". Exposé objectif — Preface de René Cassin. Paris, Les éditions internationales, 47, rue Saint André des Arts, 1958. 
Tais conclusões parecem evidentes quando se examina o relatório da comissão especial de 1956 para o "estudo da definição de agressão", que hoje temos à vista.

o relatório, pormenorizado, analítico, rico em informações, honra a comissão especial e o seu relator e lhes agradecemos o excelente trabalho apresentado.

Mostra claramente que não há quase um só aspecto importante na formulação da definição de agressão que não suscite divergências consideráveis. Quase tôdas as soluções propostas permitem intcrpretações que podem ser perigosas. $\mathrm{Ou}$, quando se desejam prevenir interpretações molestas, recorrem-se a definições que nada acrescentam aos têrmos da carta das Nações Unidas.

A delegação do Brasil ouviu sempre com a maior atenções molestas, recorrem-se a definições que nada acrescendefinir a agressão; nunca, porém, pôde discernir a vantagem ou sequer a possibilidade e, menos ainda, a oportunidade de tal definição. Não mudamos de opinião.

Pelo contrário, apesar de resoluções bem conhecidas de sessões anteriores da Assembléia geral serem optimistas quanto à possibilidade e à oportunidade da definição, a delegação do Brasil acredita que o estudo mais aprofundado da questão, levado a cabo nos últimos anos, justificaria atitude mais reservada por parte da Assembléia.

A posição da delegação do Brasil é conhecida. Eminente brasileiro, o embaixador Gilberto Amado, já apresentou o nosso pensamento em sessões anteriores da Assembléia geral. Vamos reproduzir a síntese dos seus argumentos contrários à definição de agressão:

1. a definição enumerativa, taxativa ou limitativa não poderia prever todos os casos, porque os fatos susceptíveis de serem considerados como agressão ultrapassam a mais fértil imaginação;

2. os que desejam a definição casuística não estão nunca de acôrdo sôbre o que consideram atos de agressão; 
3. cada vez mais os estados tendem a preocupar-se com novas modalidades de agressão, tais como a económica, ideológica, indireta, etc.;

4. na prática, os tratados evitam definir a agressão e a definição mista, inserta no Tratado Interamericano do Rio de Janeiro (1947), não pode ser invocada como exemplo, porque está em vigor em comunidade mais solidária e mais confiante do que a comunidade internacional;

5. a definição em têrmos genéricos resultaria mutatis-mutandis na repetição do que já está na Carta das Nações Unidas;

6. a comunidade internacional necessita do bom funcionamento do sistema de segurança coletiva, cujos defeitos não decorrem da falta da definição de agressão;

7 o ponto fraco da Carta, sob o aspecto jurídico, é a existência do chamado direito de veto, o qual, entretanto, resultou necessàriamente das condições políticas mundiais, à época da Conferência de São Francisco;

8. se bem que ajam dentro dos limites do direito internacional, a Assembléia geral e o Conselho de segurança não são tribunais, não têm competência para julgar.

Resumindo, diria que estamos convencido de que a definição em têrmos gerais havia de prestar-se a equívocos, caso se não limitasse ao emprêgo de textos da Carta das Nações Unidas. Ora, em tal caso, seria ela supérflua. Se fôsse enumerativa, não poderia compreender tôdas as formas que a agressão afinal assume na vida real. Darse-ia importância indébita a certos aspectos ou a certas modalidades de agressão; o espírito humano jamais se sentiria razoàvelmente satisfeito com a escolha das hipóteses enumeradas. 
A definição eclética, que é aparentemente seautora e parece atrair grande número de delegações, acumularia os invocados inconvenientes, ao invés de eliminá-los.

O que é importante, o que é essencial, na ocorrência de agressão, é o funcionamento do sistema de segurança coletiva, previsto na Carta das Nações Unidas. E êste funcionamento, como acabei de lembrar, não depende da aprovação de resolução da Assembléia, que defina a agressão.

Depende antes da vontade dos estados componentes, mas sobretudo dos mais poderosos dentre êles. Depende da opinião pública mundial, da sua vigilância, do seu desejo de paz e de justiça.

$O$ conselho de segurança e a Assembléia geral examinarão cada caso de ameaça à paz ou de ruptura da paz, tendo em vista a complexidade das circunstâncias políticas pertinentes. Gozam êles, pelos têrmos da Carta, de discrição considerável no cumprimento da sua tarefa. A definição de agressão, uma vez aprovada pela Assembléia, não facilitaria a tarefa, pois havia de limitar a flexibilidade e a discrição, que caracterizam a competência da Assembléia geral e do Conselho de segurança.

É evidente que a resolução da Assembléia geral não possui fôrça jurídica obrigatória, mas não pode ou não deve ser ignorada. Criaria, pelo menos, situação ambígua. De qualquer modo, pois, se havia de introduzir certo elemento de rigidês onde a carta das Nações-Unidas deliberadamente o havia evitado. $\mathrm{E}$ tal elemento de rigidês seria a definição de um têrmo a respeito do qual tantas perplexidades, dúvidas e divergências continuam a ser expressas, apesar dos estudos prolongados que têm sido feitos.

A agressão é expressão fundamental na carta. Outras expressões, porém, nela igualmente desempenham função determinante. Se há razões para desejar que o têrmo agressão seja definido, as mesmas razões deveriam levar a Assembléia geral a definir expressões tais como ameaça à paz, ruptura da paz, situação que põe em perigo a paz, e outras ainda. Entraríamos, conseqüentemente, pelo ca- 
minho das interpretações da Carta in abstracto, o que poderia levar-nos a alterar tôda a economia do instrumento constitucional da Organização.

Mesmo se, em dado momento, estivéssemos todos de acôrdo a respeito da definição precisa de agressão, não na deveríamos adotar em resolução da assembléia. Melhor seria, neste caso hipotético, emendar a Carta, modificando consideràvelmente $\mathrm{o}$ sistema atual.

A êste respeito, consideramos, como sempre, válida a opinião expressa pelo delegado do Brasil na Sociedade das Nações, o ilustre embaixador Raul Fernandes, em 1921: "não se pode aplicar o Pacto sem interpretá-lo. A Assembléia deve adotar interpretações como simples diretivas e sem votar resoluções". Quatro anos mais tarde, ainda. Raul Fernandes, com a sabedoria e clareza que sempre o caracterizam, aconselhava prudencia na interpretação do Pacto, nos têrmos seguintes: "embora as interpretações do Pacto, que resultam simplesmente da atividade da Assembléia, sejam desprovidas de qualquer caráter de interpretação autêntica e obrigatória, é óbvio que, quanto menos a Assembléia interprete o Pacto, tanto melhor, pois as interpretações, mesmo em forma carecente de fôrça obrigatória, são freqüentemente controvertidas".

As interpretações in abstracto de texto constitucional são ainda mais perigosas. Nem o Conselho de segurança nem a Assembléia geral têm necessidade delas. Êstes dois órgãos não são tribunais, cuja função seria de aplicar o texto jurídico preciso a situação determinada.

Não ignoram o direito e devem esforçar-se para criar condições favoráveis ao reino do direito, mas, sem dúvida, são essencialmente órgãos políticos, que empregam métodos políticos na defesa da paz.

A delegação do Brasil, entretanto, já fez reserva, por ocasião da VII sessão da Assembléia geral, quanto à definição de agressão no contexto do código de crimes contra a paz e a segurança da humanidade. No contexto de lei. internacional dêste gênero, destinada a ser aplicada por tribunais, seria entretanto necessário reexaminar a questão. 